\title{
Ikääntyvien yliopiston opiskelijoiden antamat merkitykset opiskelulleen
}

\author{
Aila Pikkarainen
}

\author{
Eläkeikäisten osuus väestöstä on voimakkaassa \\ kasvussa - ei vain Suomessa, vaan koko läntisessä \\ Euroopassa. Ikäihmisten yliopistoilla on oletettavasti \\ edessään kultaiset ajat. Niistä voi myös kehittyä uusi \\ erottautumisen väylä. Voidaan näet olettaa, että \\ aikaisemman sosiaalisen statuksen ylläpitäminen \\ auttaa erottautumaan Ikääntyvien yliopistossa \\ "muista" eläkeläisistä.
}

Ikääntyvien yliopistotoiminta ${ }^{1}$ on osa elinikäistä oppimista. Tämän läpi elämän jatkuvan oppimisen taustalla on ihmiskäsitys, jonka mukaan ihmisenä olemiseen kuuluu pyrkimys kehittyä koko elämän ajan. Oman persoonan jatkuva monipuolinen kehittäminen tapahtuu järjestelmällisen ja joustavan oppimisen kautta (mm. Poikela 1998). Elinikäisen oppimisen -komiteamietinnön mukaan (Komiteamietintö 1997, 2, 30) persoonallisuuden kehittämisen tukemisen lisäksi tavoitteena ovat demokraattisten arvojen vahvistaminen, toimivien yhteisöjen ja sosiaalisen yhteenkuuluvuuden ylläpitäminen, kansainvälisyyteen kasvaminen sekä innovaatioiden, tuottavuuden ja kansallisen kilpailukyvyn edistäminen (ks. Nieminen \& Sallila 1999, 13). Suomalaista yhteiskuntaa pidetäänkin elinikäisen oppimisen yhteiskuntana, jossa myös ikäihmiset toimivat väestöryhmänä aktiivisesti erilaisissa osallistumisen, harrastamisen ja yhteiskunnallisen vaikuttamisen areenoilla. Ikäihmisen oppimiskyky ja elämänkokemuksen mukana karttunut elämänviisa- us nähdään hyväksi uuden oppimisen perustaksi sekä yksilön elämänhallinnan ja tarvittaessa myös sopeutumisen välineeksi. (Vanhuspolitiikkaa vuoteen 2001, 1996, 120-121; vrt. Kansallinen Ikäohjelma.)

Elinikäistä oppimista tarjotaan nykyisin ratkaisuna moniin yksilöitä, yhteisöjä ja yhteiskuntia koskeviin ongelmiin ja uhkakuviin. Elinikäisestä oppimisesta on tehty ratkaisumalli mm. syrjäytymiseen, työttömyyteen, yksinäisyyteen, jopa terveyteen ja hyvään vanhenemiseen $(\mathrm{mm}$. Opetusministeriön koulutus ja tutkimussuunnitelma vuosille 1999-2004). Rinteen ja Salmen (1998, 140) mukaan elinikäisen oppimisen laajasta käsitteestä onkin jo mahdotonta erottaa, mikä on loppujen lopuksi oppimista ja mikä taas puhdasta sopeutumista erilaisiin ympäröiviin olosuhteisiin. Lisäksi elinikäinen oppiminen lähestyy eri ihmisiä erilaisista, merkityksiltään jopa ristiriitaisista suunnista. Oppiminen liittyy ihmisten elämään ja elämäntilanteisiin erilaisissa 
ympäristöissä ja erilaisin seurauksin. Oppimisen merkitys syntyykin suhteessa koko ihmisen elämän kontekstiin ja aikaisempiin elämänkokemuksiin. Yksilöllisen oppimisen synonyymiksi ja legitimiteetiksi ei saisi kuitenkaan tulla institutionaalinen tai organisatorinen koulutusjärjestelmä (vrt. Rinne \& Salmi 1998).

Ikääntyvien yliopiston toimintaa ohjaavat joko suoraan tai välillisesti monet kansainväliset ja kansalliset yhteiskunta- ja koulutuspoliittiset ohjelmat (mm. OECD, Unesco, EU:n ALICE-ohjelma, Vanhuspoliittinen ohjelma, Elinikäisen oppimisen komiteanmietintö, Koulutuksen ja tutkimuksen tietostrategia 2000-2004, Tutkimus- ja koulutus 1999-2004). Niissä ikäihmisten opiskelu liitetään yhteiskunnalliseen menestykseen ja onnistuneeseen vanhenemiseen. Ikääntyvien yliopistoa on kuvattu ja analysoitu viime vuosina myös useissa erilaisissa opinnäytetöissä (mm. Pitkänen 1994; Mäkäräinen 1995; Kytömaa 1998; Liutta 1998; Saari 1999; Ojala 2000). Näiden opinnäytetöiden kautta on kuvattu mm. Ikääntyvien yliopiston opiskelijoita, heidän sosioekonomista taustaansa, opiskelutoiminnan tavoitteita ja toiminnasta saatuja kokemuksia. Lisäksi on selvitetty erityisesti naisopiskelijoiden opiskelulleen antamia merkityksiä ja opetuksen didaktiikan haasteita. Ikääntyvien henkilöiden oppiminen ja opiskelu on ollut esillä myös kasvatustieteellisissä julkaisuissa (mm. Antikainen \& Huotelin 1996; Laitinen 1998; Heino \& Westermarck 1999: Sallila 2000). Kaiken kaikkiaan Ikääntyvien yliopiston toimintaa on tuotu ansiokkaasti esille niin tiedemaailmassa kuin julkisessa ja yleisessä keskustelussa.

Tämän tutkimuksen aineisto kerättiin maaliskuussa 1999 ryhmäkeskusteluna Ikääntyvien yliopiston erään seminaaritoiminnan yhteydessä. Ryhmäkeskustelu aloitettiin tutkijan esittämällä kysymyksellä: Miksi olette tulleet Ikääntyvien yliopistoon opiskelemaan eli mitkä ovat ne syyt, miksi tästä paikasta on tullut teille merkityksellinen? Ryhmäkeskusteluun osallistui viisi naista ja heidän keski-ikänsä oli 69 vuotta (vanhin 74 ja nuorin 64). Kaikilla ryhmän opiskelijoilla oli opisto- tai korkea-asteen koulutus ja erittäin pitkät työelämäjaksot takanaan. He olivat tutki-

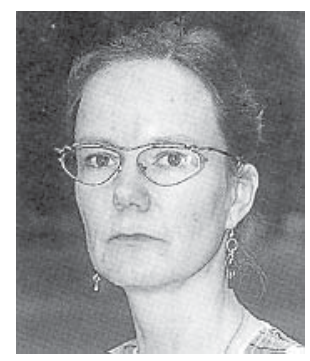

Aila Pikkarainen

muksen tekohetkellä eläkkeellä varsinaisesta työstään.

Tutkimusaineiston muodosti ryhmäkeskustelusta nauhoitetusta äänitteestä litteroitu teksti. Opiskelukokemuksista rakentuneet yksilölliset merkitykset muodostuivat fenomenologis-hermeneuttisen tutkimusanalyysin portaittaisen etenemisen kautta. Tässä lähestymistavassa oletetaan, että tutkittavat kertovat elettyä (mitä todella on tapahtunut), mutta myös koettua (mielikuvat, tunteet ja ajatukset) sekä ilmaistua (kokemukset puheena) ${ }^{2}$. Puheen kautta opiskelijat ilmaisivat henkilökohtaiset merkitykset, jotka tutkija nosti analyysin kautta litteroidusta tekstistä esiin. Seuraavaksi esitettävät opiskelutoiminnan merkitykset eivät ole yleistettävissä koko Ikääntyvien yliopiston toimintaan, mutta ne antavat yhden tulkintahorisontin tarkastella nykyistä toimintaa ja pohtia samalla toimintaan kohdistuvia odotuksia.

\section{IKÄÄNTYVIEN YLIOPISTOJA ELINIKÄINEN KOULULAISUUS}

Virallisissa määrittelyissä Ikääntyvien yliopiston toiminnalla tarkoitetaan ikäihmisille suunnattua mahdollisuutta yliopistotasoiseen opiskeluun pohjakoulutuksesta riippumatta. Toimintamuotoina ovat yleisluennot, keskusteluryhmät ja seminaarityöskentely. Opiskelun tavoitteita on määritelty myös valtakunnallisesti. Yleisenä pyrkimyksenä on mm. oman itsensä kehittäminen, yhteiskunnallisen tietoisuuden lisääminen ja omien sosiaalisten kykyjen ylläpitäminen ja edistäminen (mm. Poikela 1993, 6). Opiskelijat tuottavatkin keskustelussa lähes sanatarkasti Ikääntyvien yliopiston toiminnan muotoa määrittä- 
vää yleistä ja julkista puhetta. He korostavat, miten tieto juuri yliopistossa on tutkittua, objektiivista ja siten luotettavaa. Luennoilla esiintyvät henkilöt edustavat alansa valtakunnallista, jopa kansainvälistä huippuosaamista ja jatkossakin olisi suotavaa, ettei luennoitsijoiksi kutsuta ns. emerituksia tai emeriittoja vaan nuoria tutkijoita. Ikääntyvien yliopiston opiskelijoille on tärkeää, että on ihan oikeita esiintyjiä, jotka pitävät formaalisia luentoja juuri "meille", "ihan minulle". Koko toiminnan suunnittelussa ja toteutuksessa pidetään tiivistä yhteyttä oikean yliopiston eri laitoksiin ja esimerkiksi kansalais- tai työväenopistoihin siirtymistä ei pidetä missään muodossa suotavana. Ikääntyvien yliopiston toiminnan muotoina tulee jatkossakin olla aidot, yliopistomaiset toiminnat, kuten yleisluennot ja seminaarit. Toiminnan kontekstina tulee olla yliopiston tilat ja osallistumisen tulee tapahtua päiväsaikaan kuten muillakin yliopiston opiskelijoilla. Yliopistomainen konteksti on erittäin tärkeä3.

Opiskelijoiden puheessa kuuluu laitoskoulun organisatorinen ja institutionaalinen malli ja muoto. Nelsonin (1988) mukaan jokaisella toiminnalla on muotonsa, johon sisältyy sekä fyysisiä että sosiokulttuurisia konnotaatioita (vrt. varsinainen yliopistojärjestelmä vs. Ikääntyvien yliopisto). Tätä toiminnan muotoa ohjaavat esim. yleiset ohjeet, lait, normit, asenteet ja kielenkäyttö. Jokaisella yksilöllä on puolestaan oma kehityksellinen ja yksilöllinen rakenteensa sekä elämänhistoriansa tapahtumat ja kokemukset. Yksilö antaakin fyysiselle ja sosiokulttuuriselle toiminnan muodolle merkityksiä, jotka pohjautuvat $\mathrm{mm}$. hänen hahmotuksellisiin, symbolisiin ja affektiivisiin ominaisuuksiinsa sekä kokemuksiinsa. Merkitys on tavallaan sen järki tai mieli, jonka kautta yksilö tulkitsee jokaisessa tilanteessa tätä toiminnan muotoa eli yksilö antaa logiikan toiminnalle. Toiminnan tarkoitus muodostuu puolestaan niistä päämääristä ja tavoitteista, mitä yksilöllä on omasta toimintaan osallistumisestaan (esim. opiskelustaan Ikääntyvien yliopistossa). Siten toiminnan merkitys syntyy retrospektiivisesti menneestä ja toiminnan tarkoitus on puolestaan tulevaan suuntautumista ja toivotun tavoitteen saavuttamista. (Vrt. Nelson 1988.)
Ikääntyvien yliopiston opiskelijoilla korostuu elämänkaaren eri vaiheissa tapahtunut opiskelu. Nuorena opiskelu oli haave ja myöhemmin siitä muodostui elämäntapa. Aikuisiässä opiskelu oli virkistävä vastapaino kiireiselle työelämälle. Opiskelutoiminta jatkuu vanhuuden elämänvaiheessa Ikääntyvien yliopiston kouluorganisaatiossa. Toiminnan ulkoinen muoto on aikaisemmista elämänvaiheista tuttu ja turvallinen; on säännölliset ajoitukset ja selvät toimintatavat, lukujärjestykset ja opettajat. Opiskelu on virkistävää vastapainoa arkiselle eläkeläisen elämälle.

Kuvaan tätä ryhmäläisten elinikäistä opiskelumuodon ja toiminnan merkitystä elinikäisenä koululaisuutena. Koululaisuus-sana kuvaa mielestäni ryhmäläisten aikaisemman koulutuksen ja hyvin pitkän työuran luomaa kuvaa oppimisesta ja sen merkityksestä muodollisena osallistumisena. Mielestäni on jopa kyse elinikäisestä oppivelvollisuudesta, jota puhujat haluavat toteuttaa. Elinikäisen oppimisen käsite on ryhmäläisten tuottamaan puheeseen liian assosiatiivinen ja leimautunut käsite.

Toisaalta toiminta tuttuna ja turvallisena toistaa ryhmäläisten aikaisempaa roolia eli heidän ainutlaatuista mahdollisuutta saada oman kohorttinsa jäsenenä koulutusta (esim. opetusala, toimistotyö). Opiskelijat toteuttavat omalta osaltaan edelleen koulutuksen kautta tapahtuvaa yhteiskunnallista valikoitumistehtävää ja erottautuvat omasta ikäpolvestaan osallistumalla ns. ikääntyvien akateemiseen harrastukseen. He eivät pidä yleisesti toimintaa elitistisenä, vaikka ikätoverit ajoittain heille näin toteavat. He pitävät opiskelua myös naisille sopivana kunniallisena harrastuksena perheestä huolehtimisen rinnalla. $\mathrm{He}$ ovat joutuneet jo aikaisemmissa elämänvaiheissaan miettimään naisen erilaisia, yhteiskunnallisesti määriteltyjä ja yleisesti hyväksyttyjä rooleja tehdessään ammatillisia ja henkilökohtaisia valintojaan. Nyt tämä akateeminen vapaa-ajan toiminta tukee heidän aikaisemmissa elämänvaiheissa rakentunutta ja vakiintunutta toiminnallista rooliaan hyvin. Ikääntyvien etujoukoissa kulkeminen antaa sellaisen tunteen, että on etuoikeutettu ikääntyvien suuressa joukossa. He eivät ole sitä tavallista ikääntyvien saattuetta, jota pi- 
detään homogeenisena joukkona ja yhteiskunnallisena rasitteena. He ovat uudelleen valikoituneita omassa ikäkohortissaan, mutta samalla varastoituneita tiettyyn toiminnan muotoon ja toimintakulttuuriin. Nykyinen elämänvaihe ei ole heille vain vanhana olemista, vaan myös aktiivista toimimista ja ajassa mukana pysymistä. Ikääntyvien yliopisto antaa siihen mahdollisuuden.

\section{IKÄÄNTYVIEN YLIOPISTO SELVIYTYMISTSRATEGIANA}

Ikääntyvien yliopistossa opiskelua pidetään myös eräänlaisena elämän selviytymisstrategiana, coping-keinona. Kun "ankara arki" on tuonut elämään kaikenlaisia yllätyksiä ja ongelmia, opiskelusta on tullut pakokeino tästä ankarasta arjesta. Opiskelu on ollut selviytymiskeino aikuisiässä ja se on sitä edelleenkin iän karttuessa. Opiskelun kautta opitaan ymmärtämään maailmaa, itseä ja elämää. Opiskelusta tulee jopa terveyttä luovaa toimintaa: "aivot saavat selviytymisen tunteen". Opiskelun kautta saadaan asioita järjestykseen, loogisiksi ja rationaalisiksi. Oppiminen sanana on osalle opiskelijoista vastenmielinen ja vieras, sillä asioita pohtiessa korostuu ymmärtämisen merkitys. Ymmärtäminen saa kuitenkin ryhmäläisten puheessa yllättävän formaalisen oppimisen muodon. Opiskelun kautta opitaan hyväksymään oma tilanne ja tyydyttää toisenlaisiin mahdollisuuksiin kuin mitä on aikaisemmin elämältä odotettu tai vaadittu. Saadun formaalisen tiedon kautta saadaan ikään kuin auktoriteeteilta oikeutus omiin valintoihin, ajatuksiin, mielipiteisiin. Tämä osoittaa myös sellaista koululaisuutta, jossa on tarve ulkopuoliseen, statukseltaan riittävän korkeaan esikuvaan ja mielipiteen muodostajaan.

Voidaan ajatella, että ikääntyminenkin on ns. ankaraa arkea, josta irrottaudutaan opiskelun avulla. Eräs opiskelija kuvaa ikääntymistä ikään kuin kontekstina, jossa ansiotyö on loppunut, perhe on hajonnut ja ystävät kuolevat ympäriltä. Ikääntyminen tuodaan esiin enemmän ajallisena ja sosiaalisena roolin muutoksena kuin biologisena tai psyykkisenä vanhenemisena. Tähän ankaraan arkeen opiskelu tuo selviytymisen tunteen. Opiskelu on jotain pysyvää, ajatonta ja iätöntä, jossa biologinen, fysiologinen ja kronologinen, sosiaalinen ja jopa kokemuksellinen ikääntyminen menettää merkityksensä.

\section{IKÄÄNTYVIEN YLIOPISTO TOIMINNALLISENIDENTITEETIN JATKUVUUTENA}

Ikääntyvien yliopiston opiskelijat ovat olleet pitkään työelämässä ja eläkkeelle jääminen on aiheuttanut uudenlaisen tilanteen, jossa vanhat roolit ja tehtävät, koko toiminnallinen identiteetti on muuttunut. Eläkkeellä ollessa koetaan, että ollaan tyhjän päällä aikaisemman toiminnallisen ympäristön jättämisen jälkeen; esimerkiksi opettajina on jätetty kouluorganisaatio. Uudessa elämänvaiheessa kaivataan arkeen uutta rytmiä ja tekemistä, jotakin joka antaa tunteen, että on "oltu jossakin ihan oikeasti”. Eläkkeellä oleminen on muodostunut eräällä lailla ajattomaksi työelämän päivittäisten rutiinien puuttuessa. Toisaalta kuvataan, miten työ aiheutti loppuaikoina väsymystä ja ylimääräisiä paineita nopeiden työelämänmuutoksien vuoksi.

Ikääntyvien yliopistosta saadaan uutta jäsennystä elämään, koska sen toiminnallinen muoto on jäsentynyt tutuksi aikaisemman elämäntyön tai opiskelukokemusten kautta. Enää ei tarvitse tehdä oikeaa työtä eikä olla "pitkää päivää" töissä, vaan juuri sopivasti, että tulee tunne oikeasti jossakin olemisesta. Lähteminen Ikääntyvien yliopistoon on kuin menisi töihin: on kalenterissa jotakin. Eläkkeellä ollessa kalenteri on aluksi tyhjä ja aikataulut avoimina - Ikääntyvien yliopisto antaa päivään täytettä ja jäsentää siten viikkoa. Kuten aikaisemmin työ oli haasteellista, nyt Ikääntyvien yliopisto antaa samaa haastetta. Ikääntyvien yliopistossa opiskelu on myös ajoittain vaikeaa toimintaa ja opiskelija joutuu miettimään omaa osaamistaan sekä arvottamaan sen merkitystä. Aikaisemman toiminnallisen identiteetin mukaisesti oppimisessa on juuri tärkeää uusien haasteiden vastaanottaminen.

Oman elämän juonittaminen loogiseksi kertomukseksi voidaan kuvata toiminnallisen identiteetin jatkuvuuden tarpeena. Aikaisemmat elämän vaiheet ovat muovanneet erilaisia rooleja ja 
niihin liittyvää käyttäytymistä. Ikääntyvien yliopisto antaa mahdollisuuden jatkaa tätä identiteettiä luontevasti ja joustavasti vanhuuden elämänvaiheessa. Opiskelijat muistuttavat Kuusisen ja Tikkasen $(1994,314)$ tutkimuksessa esittämää eläkeläisten tyyppiryhmää, jolle eläkkeelle siirtyminen edustaa haastetta ja jota suunnitellaan jo etukäteen. Tähän eläkkeelle siirtyvien ryhmään kuuluvat juuri korkeammin koulutetut ja statukseltaan korkeammassa asemassa olevat henkilöt. Voidaan myös olettaa, että aikaisemman sosiaalisen statuksen ylläpitäminen Ikääntyvien yliopistossa auttaa erottautumaan muusta eläkeläisten homogeenisesta joukosta. He tekevät uuden sosiaalisen siirtymän opiskelijaksi, eivät eläkeläisiksi. ${ }^{4}$

\section{OPISKELUTOIMINNAN P्̈̈̈MÄ̈̈R̈̈T}

Opiskelijat pitävät Ikääntyvien yliopistotoimintaan osallistumista jo sinällään etuoikeutena. Useat opiskelijat ovat olleet mukana toiminnassa sen syntyhetkistä saakka ja toimintaan on osallistuttu jo ennen työelämästä eläkkeelle siirtymistä. Ikääntyvien yliopisto toimiikin eräänlaisena elämän siirtymävaiheen toimintakontekstina. Osallisuus ja omaan viiteryhmään liittyminen näkyy erityisesti yleisluennoille osallistumisessa: luennon aihetta voidaan pitää tuttuna, mutta halutaan olla kuitenkin mukana joukon jatkona. Sosiaalinen yhteisyys koetaan erityisen tärkeänä silloin, kun muut sosiaaliset suhteet ovat kaventuneet esimerkiksi leskeksi jäämisen, eläkkeelle siirtymisen tai aktiivisten harrastusten loppumisen jälkeen. Sosiaalisen vuorovaikutus on kuitenkin opiskelijan omasta aktiivisuudesta kiinni: jos jää yksin istumaan luentosalissa penkkirivin päähän, sinne saa yksin jäädäkin. Oma aktiivisuus ja halu vuorovaikutukseen toisten kanssa korostuu myös Ikääntyvien yliopistotoiminnassa.

Toisaalta toimintaan osallistuminen on suoritus: suorittaminen korostuu erityisesti pienryhmätyöskentelyssä, mutta myös suorituskeskeisyys näkyy ensin viikottaisena tapahtumien odottamisena, sitten varsinaisena konkreettisena osallistumisena ja lopuksi tapahtuman muistelemisena ja pohtimisena. Tapahtuman merkitys siten ikään kuin kolminkertaistuu. Suorittaminen korostuu myös opiskelutehtävien tekemisessä, töiden loppuunsaattamisessa ajallaan sekä palautteen ja arvioimisen arvostamisena. Tämä osoittaa myös osaltaan laitosmaisen kouluorganisaation toimintamuodon olemassaoloa.

Opiskelutoiminnan tavoitteena on myös ikäihmisten elämästä mallin ja esimerkin antaminen oman sukupolven edustajille ja myös nuoremmille sukupolville. Vanhuspoliittisessa strategiaohjelmassa esitetäänkin yleiseen vanhuskuvaan vaikuttamista siten, että ikäihmisistä välitettäisiin kuva aktiivisina ja tasa-arvoisina kansalaisina, jotka toimivat myös muissa rooleissa kuin etuisuuksien, avun ja palvelujen tarvitsijoina. (Vanhuspolitiikkaa vuoteen 2001, 1996, 124125.) Ikääntyvien yliopiston nykyisten opiskelijoiden ikäpolven koulutetut ovat jo aikaisemmin olleet esimerkkinä omalle ympäristölleen. Ikääntyvien yliopistossa opiskelijat ovat edelleen esimerkkinä tästä samasta aikaisemmin jo omaksutusta velvollisuuden tunteesta viemässä viestiä, mitä on ikääntyminen tässä yhteiskunnassa. Samalla halutaan olla vaikuttamassa oman ikäryhmän asemaan ja arvostukseen yhteiskunnassa.

\section{JOHTOPÄÄTÖKSET}

"Ja astuttuaan kerran tämän aidosti elävän oppimisen tielle, hän jättää se vasta sitten, kun hän jättää elämän. ” (J.V.Snellman)

Tutkimustuloksia ja niistä tehtyjä johtopäätöksiä tarkasteltaessa tulee erityisesti ottaa huomioon, että tutkimusaineisto muodostui yhdestä ryhmätilanteessa tuotetusta keskustelusta. Ryhmään osallistuneet henkilöt eivät ole aineistoa, vaan litteroitu, itse tutkimuskontekstista jo irrallinen teksti. Tällainen tutkimusaineisto tuottaakin usein sellaisia tuloksia, joista varsinaiset tutkittavat eivät enää tunnista itseään. Tämä ei kuitenkaan tarkoita sitä, että tutkija "keksii" aineistosta mitä tahansa, vaan hän tuottaa tarkan aineiston analyysin ja teorioiden vuoropuhelun kautta tulokset, jotka ovat argumentoitavissa (ns. hermeneuttinen kehä). 
Ikääntyvien yliopiston varsinainen opiskelutoiminta näyttäisi olevan melko valikoituneen ryhmän toimintaa. Ikääntyvien yliopiston yleiseen ja avoimeen toimintaan osallistuu satoja ikäihmisiä, mutta toiminnan vakiintuneita kävijöitä ja omasta mielestään "oikeita" opiskelijoita näyttäisi olevan vähän. Yhteisö- eli makrotasolla toiminnan periaatteet noudattavat koulutusyhteiskunnan ja elinikäisen oppimisen toimintastrategiaa. Yksilö- eli mikrotasolla toiminta kuitenkin rakentuu yksilöllisten elämäntapahtuminen ja kokemusten kautta. Esimerkiksi käsitteiden "koulutus", "opiskelu" ja "oppiminen" yksilölliset merkitykset ovat muotoutuneet aikaisemmissa elämänvaiheissa. Ikääntyvien yliopistossa näiden käsitteiden formaalit ja ei-formaalit muodot näyttävät sekoittuvan siten, että makrotasolla puhutaan ei-formaalista itsensä kehittämisestä, mutta yksilötasolla aikaisemmat, formaalit opiskelu-, oppimis- ja koulutuskäsitykset kuitenkin korostuvat. Ikääntyvien yliopistossa opiskelu -sanan ulkoinen "merkki" on ei-muodollinen, mutta sen yksilöllinen "assosiaatio" on formaalinen (koulutus, oppiminen, suoritus).

Tämän päivän Ikääntyvien yliopiston opiskelijat edustavat ns. sodan ja niukan koulutuksen sukupolvea (syntyneet ennen vuotta 1935). Tämä sukupolvi on oppinut kunnioittamaan oppiarvoja ja koulutusta, koska se oli harvojen etuoikeus ja se jäi kuitenkin useimmilta saavuttamatta. Koulutus oli yhteiskunnassa yleisenä ihanteena ja sillä oli yhteiskunnassa omat representaationsa. (mm. Kauppila 1996). Koulutuksen merkityksessä on Antikaisen (1996, 294) mukaan sukupolvittaisia eroja, joita ei voi tulkita vain henkilön ikään liittyvinä, vaan ne ovat rakentuneet yhteiskunnan muutoksen kontekstissa (mm. perheen muutokset, teollistuminen ja teollisen työn muutos, informaatioteknologian kasvu, harrastusten ja kuluttamisen muutos ym. erilaiset taloudelliset, poliittiset, kulttuuriset ja sosiaaliset muutokset). Ratkaisevia tekijöitä ovat olleet yksittäiselle henkilölle tarjolla olleet mahdollisuudet. (Antikainen 1996, 294) Lisäksi tutkimuksissa on todettu koulutuksen yleisesti kasautuvan elämänkaaren aikana niihin väestöryhmiin, joilla on jo paljon koulutusta ja yleensä vielä korkeatasoista koulutusta (vrt. Rahikainen 1999).
Näyttääkin siltä, että Ikääntyvien yliopisto toimii innovatiivisesta toimintafilosofiastaan huolimatta siinä historiallisessa koulutuksellisessa jatkumossa ja kontekstissa, josta sen tämän hetkiset opiskelijat tulevat: opiskelu on ollut statusta, erottautumisen ja sosiaalisen siirtymän väline. Se on ollut kulttuurista pääomaa ja resurssia läpi elämänkaaren ja sitä ylläpidetään ja kerätään vielä ikääntyneenäkin.

Koska kaikilla aikakausilla on ollut omat näkemyksensä koulutuksesta, oppimisesta ja opiskelusta, ovat nykyisten Ikääntyvien yliopiston opiskelijoiden opiskelun merkitykset rakentunet elämäkaaren aikaisemmista koulutus- ja opiskeluvaiheista. Korkeatasoinen aikaisempi koulutus on johtanut siihen, että myös korkeatasoinen eläkeläisten opiskelu jatkuu Ikääntyvien yliopistossa. Kun merkitykset syntyvät näiden aikaisempien kokemusten kautta, onkin aika luonnollista, ettei tämän toiminnan piiriin juuri tulla alhaisella koulutustaustalla, vähäisillä tai negatiivisilla opiskelukokemuksilla.

Oman toiminnallisen identiteetin kannalta opetusalalla ja sitä lähellä olevilla aloilla toimineille (toimisto-, kirjasto- ja julkinen sektori) Ikääntyvien yliopisto antaa jatkuvuuden ja turvallisuuden tunteen toiminnan muodon tuttuuden vuoksi. Aikaisemmin työelämään liittyneet merkitykset siirtyvät eläkeiässä opiskelutoimintaan. Toiminnan muoto tukee ns. laitosoppimisen jatkamista sekä elinikäistä koululaisen ja oppijan identiteettiä. Samoin opiskelu selviytymiskeinona jatkuu iästä riippumatta - ikääntyneenä sitä käytetään vanhenemisen mukanaan tuomiin sosiaalisiin muutoksiin.

Ikääntyvien yliopiston muodostuminen ns. ikänaisten eliittiakatemiaksi tai yliopistolliseksi vapaa-ajan toiminnaksi (Varja 2000, 147-152) osoittavat niitä kriittisiä kannanottoja, joita tätä toimintaa kohtaan on viime aikoina esiintynyt. Ahteenmäki-Pelkonen $(1999,137)$ esittää, että opiskelevasta vanhuksesta on tullut ikääntyvän ihmisen ideaali. Voidaankin pohtia, onko ikääntyneen opiskelijan roolimalli yhteiskunnalle edullisempi kuin normaalien vanhenemismuutosten, sairauksien ja toimintakyvyn alenemisen kanssa 
kamppailevan vanhuksen malli. Paradoksaalista on sekin, että yleisesti iäkkäiden henkilöiden arkipäivän elämästä selviytymistä, omatoimisuutta ja itsenäistä asumista - toisin sanoen jokapäiväisten taitojen osaamista ja hallintaa korostetaan enemmän kuin heidän mahdollista koulutuksellista taustaansa tai muodollista oppineisuuttaan (vrt. Lahn 2000, 49). Lisäksi juuri vanhuuspoliittisessa strategiaohjelmassa esitetään nykyisten kulttuuri- ja koulutustarjonnan lisäksi Ikääntyvien yliopistoihin mm. ihmissuhdekoulutusta, elämänkaaritarkastelua ja kansalaistaitoja itsenäisen arkielämän selviytymisen tueksi (Vanhuspolitiikkaa vuoteen 2001, 1996, 124-25). Akateemisen koulutustaustan on todettu olevan positiivisesti yhteydessä iäkkäiden henkilöiden hyvään toimintakykyyn ja ennustavan hyvin itsenäistä selviytymistä päivittäisessä elämässä (mm. Heikkinen 2001). Toisaalta koulutustaustan tasoittuessa, voidaan olettaa koulutustaustan merkitysten tasoittuvat.

Yksilöllisesti muotoutuneet koulutukselliset biografiat ja niiden kautta retrospektiivisesti rakentuneet merkitykset näyttäisivät olevan ratkaisevia yksilön valikoituessa Ikääntyvien yliopiston opiskelijaksi. Näiden yksilöllisten merkitysten kautta juuri tietyt ihmiset ohjautuvat opiskelutoimintaan mukaan. Tulevaisuuden Ikääntyvien yliopiston onkin otettava huomioon uusien ikäkohorttien erilaiset identiteetit ja rakennettava niitä ennakoiden uudenlaisia palveluja. Uusilla kohorteilla on erilaiset elämänpolut, joissa esimerkiksi koulutukset ja työsuhteet sekä erilaiset toiminnalliset identiteetit vuorottelevat ja aikaisemmat elämänkokemukset ja merkitykset suuntaavat eläkeiän toimintaa uudella tavalla. Ahteenmäki-Pelkonen $(1999,121)$ esittääkin, että ikääntyvien oppimista koskevan tutkimuksen tulisi olla niin hermeneuttista kuin emansipatoristakin. Ikääntyvien yliopistoa kehitettäessä tuleekin pyrkiä ymmärtämään ikääntyneiden tapaa ajatella ja sitä kautta myös toimia opiskelijoina. Nykyistä ikääntyvien henkilöiden opiskelutoimintaa tulee tehdä myös näkyväksi sekä itse toimijoille että suunnittelijoille uudella tavalla, jotta uutta toimintaa ja innovaatioita voidaan rakentaa. Muutoin toiminta jää kehämäiseksi itseään toistavaksi toiminnaksi. Tämän artikkelin tarkoituksena onkin ollut ns. emansipatorinen tiedonintressi, jossa on avattu Ikääntyvien yliopistotoimintaa yksilöllisenä merkitysstruktuurina ja siten melko staattisena ja pysyvänä elämänkaaren mukaan rakentuneena toimintamallina, jossa toteutuu mm. sosiaalisen siirtyminen, valikoituminen ja varastoituminen tiettyyn koulutukselliseen instituutioon. Uudenlaisena sosiaalisena arkkitehtuurina Ikääntyvien yliopisto tulee tehdä näkyväksi, reflektiivisen tarkkailun kohteeksi, jolloin sen mahdolliset toiminnalliset lukkiutumat voidaan havaita ja toimintaa kehittää uusia haasteita paremmin vastaaviksi ${ }^{5}$ (vrt. Jyrkämä 1999).

Suomalainen kuusivuotias lapsi osallistuu suunnitelmalliseen ja tavoitteelliseen esiopetukseen ja eläkeläinen terveyttä edistävään Ikääntyvien yliopistotoimintaan. Tätä elinikäistä koululaisuutta vaaditaan yksilöltä sekä kansallisen menestymisen turvaamiseksi että yksilöllisen hyvinvoinnin saavuttamiseksi. Eliniän jatkuvasti pidentyessä ja koulutuspolkujen monipuolistuessa vaihtoehtona voisikin olla Antikaisen kuvaaman (2001) elämänlevyisen oppimisen ja elämänpituisen (elinikäisen) oppimisen yhdistäminen. Tässä elämänlaajuisessa oppimisessa opiskelua ja oppimista ei mitattaisi vain määrinä, kestoina, tiheyksinä tai formaalisina muotoina vaan myös yksilöllisinä merkityksinä ${ }^{6}$. Elämänlaajuiseen oppimiseen kuuluisivat siten myös jokaisen ikäihmisen yksilöllinen elämänkokemus, elämänviisaus ja arjen osaaminen.

\section{Viitteet}

1 Ikääntyville henkilöille tarkoitettu yliopistoidea hahmottui läntisissä teollisuusmaissa 1970-luvulla ja se on lähes kolmenkymmenen vuoden toimintansa aikana levittäytynyt kymmeniin maihin ja satoihin koulutusorganisaatioihin (mm. Laitinen 1998). Näistä organisaatioista käytetään eri maissa mm. nimikkeitä seniorien yliopisto, kolmannen iän yliopisto (U3A), kaiken ikäisten yliopisto (UTA) ja eläkeläisten yliopisto (Hietaluoma 1999, 141). Käytän tässä artikkelissa käsitettä "Ikääntyvien yliopisto" tar- 
koittamaan suomalaista ikäihmisten yliopistotoimintaa.

2 Vrt. Saarenheimo 1997; Granfelt 1999; Juvakka 2000; Riceur 2000. Fenomenologishermeneuttisen analyysin tulokset esitetään ilman suoria lainauksia, mutta tuloksissa pyritään ilmaisemaan mahdollisimman tarkasti kaikki ne alkuperäiset tutkittavien ilmaukset, joista tutkija merkitykset rakentaa.

3 Eräs opiskelija kertoi, kuinka hän on saanut yliopistosta tarpeekseen aikaisemmissa elämänvaiheissaan. Hänestä Ikääntyvien yliopistotoiminta voisi tapahtua yhtä hyvin opistoissa. Samat tavoitteet voitaisiin saavuttaa siellä samoilla toiminnoilla ja luennoitsijoilla. Toiset ryhmäläiset perustelivat entistä tiukemmin yliopistomaista toimintaa ja sen etuja. Mielestäni tämä, äskettäin mukaan tulleen opiskelijan mielipide voi olla osoitus uudesta tulevaisuuden haasteesta toiminnan kehittämiseksi. Hän ikään kuin ilmaisi tulevaisuuden opiskelijoiden opiskelutoiminnan merkityksen uuden idun ja jopa asennemuutoksen nykyistä toiminnan muotoa kohtaan.

4 Osa opiskelijoista ilmaisi halunsa olla vielä töissä, jos se vain olisi mahdollista. Suomessa on heidän mielestään liian alhainen eläkeikä ja vielä 70-vuotiaanakin voisi olla työelämässä, jos se vain muokattaisiin ikääntyvälle työntekijälle sopivaksi. Tämä mielipide herätti kuitenkin joissakin opiskelijoissa ajatuksia siitä, että eläkkeelle siirtyminen pitkän työuran jälkeen aiheuttaa kriisin, joka saattaa kestää jopa kolmekin vuotta. Tässä muutosvaiheessa päivittäistä elämää elää vielä työpaikan ajoitusten mukaan ennen kuin saa päiviinsä uutta ohjelmaa ja sisältöä.

\section{Käsitteet lainattu ja sovellettu Jyrkämältä (1999)}

6 Elämänpituinen oppiminen x elämänlevyinen oppiminen $=$ elämänlaajuinen oppiminen

\section{Lähteet}

AHTEENMÄKI-PELKONEN, L. (1999) Ikääntyvien opiskelu - hyödyllinen harrastus? Ss. 122-141 teoksessa teoksessa Sallila, P. \& Niemelä, S. (toim.) Sivistystyö osaamisyhteiskunnassa. Aikuiskasvatuksen 40. vuosikirja. Kansanvalistusseura ja Aikuiskasvatuksen Tutkimusseura. Helsinki: BTJ.

ANTIKAINEN, A. (1996) Merkittävät oppimiskokemukset ja valtautuminen. Ss. 251-296 teoksessa Antikainen, A. \& Huotelin, H. (toim.): Oppiminen ja elämänhistoria. Aikuiskasvatuksen 37. vuosikirja. Kansanvalistusseura ja Aikuiskasvatuksen Tutkimusseura. Helsinki: BTJ.

ANTIKAINEN, A. (2001). Kansainvälinen vertailu elinikäisestä oppimisesta. Ss. 99-125 teoksessa Heikkinen, E. \& Tuomi, J. (toim.) Suomalainen elämänkulku. Helsinki: Tammi.

ANTIKAINEN, A., \& HUOTELIN, H. (1996) Oppiminen ja elämänhistoria. Aikuiskasvatuksen 37. vuosikirja. Kansanvalistusseura ja Aikuiskasvatuksen Tutkimusseura. Helsinki: BTJ.

GRANFELT, R. (1999) Kertomuksia naisten kodittomuudesta. Helsinki: Suomalaisen kirjallisuuden seura.

HEIKKINEN, E. (2001) Terve vanheneminen - utopia vai realistinen mahdollisuus? Ss.217-234 teoksessa Heikkinen, E. \& Tuomi, J. (toim.) Suomalainen elämänkulku. Helsinki: Tammi.

HEINO, P., \& WESTERMARCK, H. (toim.) (1999) Studia generalia. Ikääntyminen ja oppiminen. Helsingin yliopiston vapaan sivistystyön toimikunta. Helsinki: Yliopistopaino.

HIETALUOMA, A. (1999) Oppia koko ikä. Ss. 140-155 teoksessa Jääskeläinen, M., Lamberg, M., Penttinen, L., \& Saarimäki, M. (toim.): Open uni. Avointa keskustelua oppimisesta. Jyväskylä: Jyväskylän yliopisto, Avoin yliopisto.

JUVAKKA, T. (2000) Elämää risteyskohdissa. Hermeneuttiseen fenomenologiaan ja kehollisuuteen perustuva tutkimus 15-16 -vuotiaiden nuorten toivon kokemuksista heidän jokapäiväisessä elämässään. Kuopion yliopisto, Hoitotieteen laitos. Kuopio: Kuopion yliopiston painatuskeskus, Julkaisuja E. Yhteiskuntatieteet 82.

JYRKÄMÄ, J. (1999) Toimintatutkimus ja sosiaaliset toimintakäytännöt. Giddensiläisiä näkökulmia toimintatutkimukseen. Ss. 137-153 teoksessa Heikkinen, H.L.T., Huttunen, R., \& Moilanen P. (toim.): Siina tutkija missä tekijä. Toimintatutkimuksen prusteita ja näköaloja. Jyväskylä: Atena, PS-viestintä.

KANSALLINEN IKÄOHJELMA (2000) Opetusministeriön toimenpiteet 1999-2000. Opetusministeriön ikäohjelman työryhmän raportti. Helsinki: Opetusministeriö.

KOULUTUKSEN JA TUTKIMUKSEN TIETOSTRATEGIA 2000-2004. Http://minedu/tietotsrategia/tietostrategia. html.(20.5.2001).

KAUPPILA, J. (1996) Koulutus elämänkaaren rakentajana. Ss. 45-108 teoksessa Antikainen, A. \& Huotelin, H. (toim.): Oppiminen ja elämänhistoria. Aikuiskasvatuksen 37. vuosikirja. Kansanvalistusseura ja Aikuiskasvatuksen Tutkimusseura. Helsinki: BTJ.

KOMITEAMIETINTÖ (1997) Oppimisen ilo. Elinikäi- 
sen oppimisen strategia. KM 1997: 14. Helsinki: Edita.

KUUSINEN, J., \& TIKKANEN, T. (1994) Eläkkeelle siirtyminen ja eläkkeelle valmennus. Ss. 309-323 teoksessa Kuusinen, J., Heikkinen, E., Huuhtanen P., Ilmarinen, J., Kirjonen, J. ym. Ikääntyminen ja työ. Helsinki: WSOY, Työterveyslaitos.

KYTÖMAA, K. (1998) Ikäihmisten yliopiston opiskelijan elämäkertakoulutuksen näkökulmasta. Helsingin yliopisto, Kasvatustieteen laitos. Aikuiskasvatustieteen proseminaarityö. Kirjoittajan hallussa.

LAHN, L.C. (2000) Ikääntyvät oppijat oppivassa yhteiskunnassa. Ss. 41-72 teoksessa Sallila, P. (toim.): Oppiminen ja ikääntyminen. Aikuiskasvatuksen 41. vuosikirja. Kansanvalistusseura ja Aikuiskasvatuksen Tutkimusseura. Helsinki: BTJ.

LAITINEN, A. (toim.) (1998) Kolmannen iän yliopistot Suomessa. Elämänkokemuksesta tietoon ja oppimiseen. Jyväskylän Ikääntyvien yliopiston tutkielmat 1. Jyväskylä: Jyväskylän yliopistopaino

LIUTTA, A. (1998) Vanhuusdidaktiikan vaatimukset. Tampereen yliopisto, Kasvatustieteen tiedekunta, Aikuiskasvatuksen laudatur-tutkielma.

MÄKÄRÄINEN, P. (1995) Ikäihmisten yliopistossa opiskelun merkitys. Helsingin yliopisto, Kasvatustieteen laitos. Kasvatustieteen pro gradu -tutkiel$\mathrm{ma}$.

NELSON, D. (1988) Occupation: Form and performance. American Journal of Occupational Therapy 42: 633-641.

NIEMELÄ, S., \& SALLILA, P. (1999) Johdanto: Vapaa sivistystyö osaamisen yhteiskunnassa. Ss. 7-20 teoksessa Sallila, P. \& Niemelä, S. (toim.) Sivistystyö osaamisyhteiskunnassa. Aikuiskasvatuksen 40. vuosikirja. Kansanvalistusseura ja Aikuiskasvatuksen Tutkimusseura. Helsinki: BTJ.

OJALA, H. (2000) "On siellä joku sellainen kiva fiilis!" Ikäihmisten yliopistossa opiskelun merkitys ikääntyvän naisen elämänkulussa. Tampereen yliopisto, Kasvatustieteen laitos. Aikuiskasvatuksen pro gradu -tutkielma.

OPETUSMINISTERIÖ (2000) Koulutus ja tutkimus vuosina 1999-2004. Kehittämissuunnitelma. Helsinki: Edita.

PITKÄNEN, A. (1994) Opiskellen itsensä toteuttamiseen. Miten Ikäihmisten yliopiston luennot koettiin. Tampereen yliopisto, Täydennyskoulutuskeskus. Julkaisusarja A 4/1994.

POIKELA, S. (1993) Ikäihminen, elämänkulku ja oppiminen. Elämänkokemuksesta kokonaisvaltaiseen oppimiseen Ikäihmisten yliopistossa. Tampereen yliopiston Täydennyskoulutuskeskuksen julkaisusarja A 2/93. Tampere.

POIKELA, S. (1998) Elämänkokemus ja oppiminen ikäihmiset yliopistossa. Ss. 33-42 teoksessa Laitinen, A. (toim.) Kolmannen iän yliopistot Suomessa. Elämänkokemuksesta tietoon ja oppimiseen. Jyväskylän Ikääntyvien yliopiston tutkielmat 1 . Jyväskylä: Jyväskylän yliopistopaino

RAHIKAINEN, M. (1999) Aikuiskoulutus Suomessa ja muualla Euroopassa. Keskustelualoitteita. Helsinki: Valtion taloudellinen tutkimuskeskus.

RICEUR, P. (2000) Tulkinnan teoria. Diskurssi ja merkityksen lisä. Suom. H. Kujansivu. Helsinki: Tutkijaliitto.
RINNE, R., \& SALMI . (1998) Oppimisen uusi järjestys. Tampere: Vastapaino.

SAARENHEIMO, M. (1997) Jos etsit kadonnutta aikaa. Vanhuus ja oman elämän muisteleminen. Tampere: Vastapaino.

SAARI, S. (1999) Tieteellisen tiedon ja tutkimuksen teillä. Tutkielma Helsingin yliopiston Ikäihmisten yliopiston tutkimusseminaaritoiminnasta siihen osallistuneiden opiskelijoiden kokemusten näkökulmasta. Helsingin yliopisto, Kasvatustieteen laitos. Aikuiskasvatustieteen proseminaarityö. Kirjoittajan hallussa.

SALLILA, P. (toim.) (2000) Oppiminen ja ikääntyminen. Aikuiskasvatuksen 41. vuosikirja. Kansanvalistusseura ja Aikuiskasvatuksen Tutkimusseura. Helsinki: BTJ.

TUOMISTO, J. (1999) Vapaa sivistystyö 2000-luvun kynnyksellä - uudet tehtävät ja vaatimukset. Ss. 23-55 teoksessa Sallila, P. \& Niemelä, S. (toim.): Sivistystyö

VANHUSPOLITIIKKAA VUOTEEN 2001. Suomen vanhuspoliittinen tavoite ja strategiatoimikunnan mietintö (1996). Komiteamietintö 1996:1. Sosiaali- ja terveysministeriö. Helsinki: Edita.

VARJA, M. (2000) Ikäihmisten yliopisto vuonna nolla. Ss.142-163 teoksessa Sallila, P. (toim.): Oppiminen ja ikääntyminen. Aikuiskasvatuksen 41. vuosikirja. Kansanvalistusseura ja Aikuiskasvatuksen Tutkimusseura. Helsinki: BTJ.

\section{Jälkisanat}

Arvostan Ikääntyvien yliopiston monivuotista uraa uurtavaa ja innovatiivista työtä sekä sen monivuotisia kehittäjiä, suunnittelijoita ja toimijoita. Haluan kiittää tutkimukseeni osallistuneita henkilöitä heidän avoimmuudestaan ja luottamuksestaan. Ymmärrykseni tutkimastani ilmiöstä on vain "toistaiseksi riittävä” ja toivon sen kehittyvän jatkuvasti yhteisen keskustelun kautta. AP

Artikkeli saapui toimitukseen 23.5.2001. Se hyväksyttiin julkaistavaksi 13.12.2001. 